\title{
MSX1 Gene
}

National Cancer Institute

\section{Source}

National Cancer Institute. MSX1 Gene. NCI Thesaurus. Code C40967.

This gene is involved in transcriptional repression and embryogenesis. 